This article was downloaded by: [University of Sydney]

On: 04 May 2015, At: 07:59

Publisher: Routledge

Informa Ltd Registered in England and Wales Registered Number: 1072954

Registered office: Mortimer House, 37-41 Mortimer Street, London W1T

3J H, UK

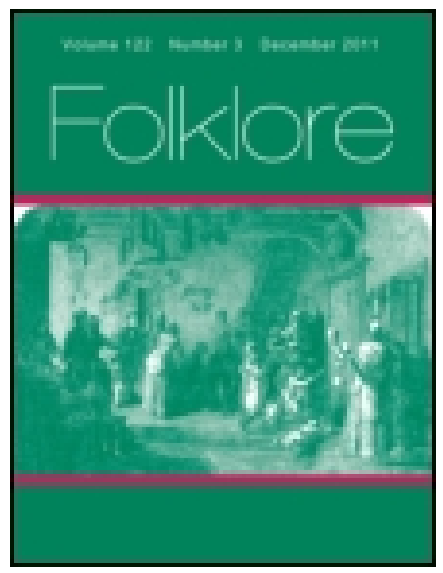

\title{
Folklore
}

Publication details, including instructions for authors and subscription information:

http:// www. tandfonline.com/loi/ rfol20

\section{Pre-Animistic Religion}

R. R. Marett M.A.

Published online: 14 Feb 2012.

To cite this article: R. R. Marett M.A. (1900) Pre-Animistic Religion, Folklore, 11:2, 162-184, DOI: 10.1080/0015587X.1900.9720526

To link to this article: http:// dx. doi. org/ 10.1080/0015587X.1900.9720526

\section{PLEASE SCROLL DOWN FOR ARTICLE}

Taylor \& Francis makes every effort to ensure the accuracy of all the information (the "Content") contained in the publications on our platform. However, Taylor \& Francis, our agents, and our licensors make no representations or warranties whatsoever as to the accuracy, completeness, or suitability for any purpose of the Content. Any opinions and views expressed in this publication are the opinions and views of the authors, and are not the views of or endorsed by Taylor \& Francis. The accuracy of the Content should not be relied upon and should be independently verified with primary sources of information. Taylor and Francis shall not be liable for any losses, actions, claims, proceedings, demands, costs, expenses, damages, and other liabilities whatsoever or howsoever caused arising directly or indirectly in connection with, in relation to or arising out of the use of the Content.

This article may be used for research, teaching, and private study purposes. Any substantial or systematic reproduction, redistribution, reselling, loan, sub-licensing, systematic supply, or distribution in any form to anyone is 
expressly forbidden. Terms $\&$ Conditions of access and use can be found at http://www.tandfonline.com/page/terms-and-conditions 
the child-stealing witch from the heights of the Carpathian Mountains, through Roumania; the south of Russia, the Plains of the Balkans, as far as Old Byzantium, thence to the cloisters of Syria, through Palestine, and on to the Valley of the Nile: A far-travelled charm indeed, and who knows how far it will travel still?

M. GASTER.

\section{PRE-ANIMISTIC RELIGION.}

BY R. R. MARETT, M.A.

\section{(Read at Meeting of November 15 th, I899')}

THE object of the present paper is simply to try to give relatively definite shape to the conception of a certain very primitive phase of Religion, as Religion may for anthropological purposes be understood. The conception in question will strike many, I daresay, as familiar, nay possibly as commonplace to a degree. Even so, however, I venture to think that it is one amongst several of those almost tacitly accepted commonplaces of Comparative Religion which serve at present but to "crib, cabin, and confine" the field of active and critical research. Comparative Religion is still at the classificatory stage. Its genuine votaries are almost exclusively occupied in endeavouring to find "pigeon-holes" wherein to store with some approach to orderly and distinct arrangement the vast and chaotic piles of "slips" which their observation or reading has accumulated. Now in such a case the tendency is always to start with quite a few pigeon-holes, and but gradually and, as it were, grudgingly, to add to their number. On the other hand /considerable division and sub-division of topics is desirable, both in the interest of specialised study and in order to baffle and neutralise the efforts of popularisers to enlist prejudice on the side of one or another 
would-be synoptic version of the subject, based on some narrow and fragmentary view of the data as provided by current science. Nay, so essential is it to detach "workable" portions of the evidence for separate and detailed consideration, that it is comparatively unimportant whether the divisions at any moment recognised and adopted be capable of exàct co-ordination in respect to one another, so long as each taken by itself is clearly marked and leads immediately to business. Thus in the present case I have ventured to call attention to a phase of early Religion which, I believe, only needs clearly marking off by the aid of a few technical designations, to serve as a rallying point for a quantity of facts that have hitherto largely "gone about loose." I have therefore improvised some technical terms. I have likewise roughly surveyed the ground covered by the special topic in question, with a view to showing how the facts may there be disposed and regimented. Choicer technical terms no doubt may easily be found. Moreover my illustrations are certainly anything but choice, having been culled hastily from the few books nearest to hand. May I hope, however, at least to be credited with the good intention of calling the attention of anthropologists to the possibilities of a more or less disregarded theme in Comparative Religion; and may I, conversely, be acquitted of any design to dogmatise prematurely about Religious Origins because I have put forward a few experimental formulie, on the chance of their proving useful to this or that researcher who may be in need of an odd piece of twine wherewith to tie his scopex dissolutz into a handy, if temporary, besom?

Definitions of words are always troublesome; and Religion is the most troublesome of all words to define. Now for the purposes of Anthropology at its present stage it matters less to assign exact limits to the concept to which the word in question corresponds, than to make sure that these limits are cast on such wide and generous lines, as to exclude no feature that has characterised Religion at any moment in the 
long course of its evolution. Suffice it, then, to presuppose that the word stands for a certain composite or concrete state of mind wherein various emotions and ideas are together directly provocative of action. Let it be likewise noted at the start, that these emotions and ideas are by no means always harmoniously related in the religious consciousness, and indeed perhaps can never be strictly commensurate with each other. Now for most persons, probably, the emotional side of Religion constitutes its more real, more characteristic feature. Men are, however, obliged to communicate expressly with each other on the subject of their religious experience by the way of ideas solely. Hence, if for no other reason, the ideas composing the religious state tend to overlay and outweigh the emotional element, when it comes to estimating man's religious experience taken at its widest. Thus we catch at an idea that reminds us of one belonging to an advanced creed and say, Here is Religion; or, if there be found no clear-cut palpable idea we are apt to say, There is no Religion here; but whether the subtle thrill of what we know in ourselves as religious emotion be present there or no, we rarely have the mindfulness or patience to inquire, simply because this far more. delicate criterion is hard to formulate in thought and even harder to apply to fact.

Now the object of this paper is to grope about amongst the roots of those beliefs and practices that at a certain stage of their development have usually been treated as forming a single growth which is labelled Animism, or more properly Animistic Religion. 'It is a region hard to explore, because the notions that haunt it are vague and impalpable; the religious sense (if such it may be called) manifesting itself in almost unideated feelings that doubtless fall to a large extent outside the savage "field of attention," and at any rate fall wholly outside our field of direct observation. Now, even where there undeniably do exist precise ideas of the savage mind for Anthropology to grasp and garner, 
everyone is aware how exceedingly difficult it is to do them justice. How much more difficult, therefore, must it be in the case of the earliest dim heart-stirrings and fancies of the race, to truthfully preserve the indistinctness of the original, and yet make clear the nature of that germinal source whence our own complex beliefs and aspirations must be supposed to have arisen.

Animism as a technical term applied to Religion, calls attention to the presence of a more or less definite creed or body of ideas. According to Dr. Tylor, who presented it to Anthropology, it signifies "the belief in the existence of Spiritual Beings," that is to say, of "spirits" in the wide sense that includes "souls." A looser use of the word by some writers, whereby it is made to cover the various manifestations of what is commonly but cumbrously styled the "anthropomorphic" tendency of savage thought, will here be ignored, and a fresh expression substituted, seeing that such an extension of its meaning robs the term of its exacter and more convenient connotation, and, further, seeing that it has failed to win general recognition from men of science.

No anthropologist, of course, has ever supposed himself able fully and finally to explain the origin of the belief in souls and spirits. Indeed, with regard to absolute origins of all kinds we had best say at once with the philosopher that "Nothing is strictly original save in the sense that everything is." Dr. Tylor and others, however, have with great plausibility put forward a view as to the specifically formative source of the idea, in what has been nicknamed "the dream-theory." This theory asserts that the prototype of soul and spirit is to be sought especially in the dream-image and trance-image-that vision of the night or day that comes to a man clothed distinctively in what Dr. Tylor describes as "vaporous materiality," or, as the

'Print. Cult. (3rd edition), i., d24. 
Greenland angekok puts it, "pale and soft so that if a man try to grasp it he feels nothing "-par levibus ventis volucrique simillima somno. Perhaps it is only due to Mr. Lang's latest researches ${ }^{1}$ to say with regard to this theory that its centre of gravity, so - to speak; has of late shown signs of shifting from dream to trance, so that "the hallucination-theory" might possibly now prove the more appropriate descriptive title. I shall not, however, pause to inquire whether the "thrill" of ghost-seeing is likely to have given form and character to the religious emotions of the savage, more directly or forcibly than the less unfamiliar, yet more kindly and sympathetic, appearance of "dream-faces"; nor, again, whether the practical proofs, as they may be called, of Spiritualism (which after all is but another name for Animism), ${ }^{2}$ I mean clairvoyance and the like, were brought into earlier or greater prominence by normal dreamers or by abnormal "seers." It is enough for my present purpose to assume that Animism, the belief in the existence of visionary shapes, whether of the dead or sui juris, became with the savage at a certain stage of his development, the typical, nay almost the universal, means of clothing the facts of his religious experience in ideas and words, and the typical and all but universal theory on which he based his religious practice. And this being assumed, we reach our special problem: Before, or at any rate apart from, Animism, was early man subject to any experience, whether in the form of feeling or of thought, or of both combined, that might be termed specifically "religious"?

Let us begin by asking ourselves what was the precise ground originally covered by animistic belief. The answer, if purely tentative, is soon made. The savage as we know him to-day believes in an infinitely miscellaneous collection of spiritual entities. "To whom are you praying?" asked

2 The Making of Religion, Longmans, Green, and Co., I 898 .

' Prim. Cult., i., 426. 
Hale of a Sakai chief at one of those fruit festivals so characteristic of the Malay peninsula. "To the Hantus (spirits)," he replied-"the Hantus of the forest, of the mountains, of the rivers, the Hantus of the Sakai chiefs who are dead, the Hantus of head-ache and stomach-ache, the Hantus that make people gamble and smoke opium, the Hantus that send disputes, and the Hantus that send mosquitoes."1 Now are all these Hantus, animistically speaking, on a par, or are some original, others derived ?' I take it that I am at one with most orthodox upholders of Animism in supposing the Hantus of the dead to be the original animæ whence the rest have derived their distinctively animistic, that is to say ghostly, characteristics. For this view it will perhaps be enough to allege a single reason. The revenant of dream and hallucination in its actual appearance to the senses, presents so exactly and completely the type to which every spirit, however indirect its methods of selfmanifestation, is believed and asserted to conform, that I am personally content to regard this conclusion as one amongst the few relative certainties which Anthropology can claim to have established in the way of theory. Suppose this granted, then we find ourselves confronted with the following important train of questions, yielding us a definite nucleus and rallying-point for our present inquiry: "How came an animistic colour to be attached to a number of things not primarily or obviously connected with death and the dead? What inherent general character of their own suggested to man's mind the grouping together of the multifarious classes of so-called 'spiritual' phenomena as capable of common explanation? Was not this common explanation the outcome of a common regard, a common and yet highly specific feeling or emotion? And is not this feeling related to the ideas wherein it finds as it were symbolical expression-as for example to the animistic 
idea-as something universal and fixed to something par: ticular and transitory?"

Now by way of answer to these questions, let me repeat, I have no brand-new theory to propound. The doctrine. that I now wish to formulate unambiguously, and at the same time, so far as may be possible within the limits of a short article, to supply with a basis of illustrative fact, is one that in a vague and general form constitutes a sort of commonplace with writers on Religious Origins. These writers for the most part profess, though not always in very plain or positive terms, to discern beneath the fluctuating details of its efforts at self-interpretation, a certain Religious Sense, or, as many would call it, Instinct, whereof the component "moments" are Fear, Admiration, Wonder, and the like, whilst its object is, broadly speaking, the Supernatural. Now that this is roughly and generally true no one, I think, is likely to deny. Thus to put the matter as broadly as possible, whether we hold with one extreme school that there exists a specific religious instinct, or whether we prefer to say with the other that man's religious creeds are a by-product of his intellectual development, we must, I think, at any rate admit the fact that in response to, or at any rate in connection with, the emotions of Awe, Wonder, and the like, wherein feeling would seem for the time being to have outstripped the power of "natural," that is reasonable, explanation, there arises in the region of human thought a powerful impulse to objectify and even personify the mysterious or. "supernatural" something felt, and in the region of will a corresponding impulse to render it innocuous, or better still propitious, by force of constraint, communion, or conciliation. Supernaturalism then, as this universal feel. ing taken at its widest and barest may be called, might, as . such, be expected to prove not only logically, but also in some sense chronologically prior to Animism, constituting as the latter does but a particular ideal embodiment of the former. 
The appeal to fact that will occupy the rest of this paper, cursory though it must be in view of our space conditions, will suffice, I hope, to settle the matter. First, let us remind ourselves by the help of one or two typical quotations how widely and indiscriminately Supernaturalism casts its net. Thus Ellis writes of the Malagasy: "Whatever is great, whatever exceeds the capacity of their understandings, they designate by the one convenient and comprehensive appellation, Andriamanitra. Whatever is new and useful and extraordinary is called god. Silk is considered as god in the highest degree, the superlative adjective being added to the noun-Andriamanitra-indrinda. Rice, money, thunder and lightning, and earthquake are all called god. Their ancestors and a deceased sovereign they designate in the same manner. Tarantasy or book they call god, from its wonderful capacity of speaking by merely looking at it. Velvet is called by the singular epithet, ' son of god." I So too of the Masai, though far lower than the Malagasy in the scale of culture, the account given by Joseph Thomson is precisely similar. "Their conception "of the deity," he says, "seems marvellously vague. I was Ngai. My lamp was Ngai. Ngai was in the steaming holes. His house was in the eternal snows of Kilimanjaro. In fact, whatever struck them as strange or incomprehensible, that they at once assumed had some connection with $N g a i^{\prime \prime 2}$ As I have said, such quotations are typical and might be multiplied indefinitely. Andriamanitra and $N g a i$ reappear in the Wakan of the North American Indian, the Mana of the Melanesian, the Kalou of the Fijian, and so on. It is the common element in ghosts and gods, in the magical and the mystical, the supernal and the infernal the unknown within and the unknown without. It is the Supcrnatural or Supernormal, as distinguished from the

1 Ellis, Hist. of Madagascar, i., 391-2.

2 Thomson, Masailand, 445. 
Natural" or Normal; that in short which, as Mr. Jevons phrases it, "defeats reasonable expectation." "Or perhaps another and a better way of putting it, seeing that it calls attention to the feeling behind the logic, is to say that it is the Awful, and that everything wherein or whereby it manifests itself is, so to speak, a Power of Awfulness, or, more shortly, a Power (though this, like any other of our verbal equivalents, cannot but fail to preserve the vagueness of the original notion).1 Of all English words Awe is, I think, the one that expresses the fundamental Religious Feeling most nearly. Awe is not the same thing as "pure funk." "Primus in orbe deos fecit timor" is only true if we admit Wonder, Admiration, Interest, Respect, even Love perhaps, to be, no less than Fear, essential constituents of this elemental. mood.

Now ghosts and spirits are undoubtedly Powers, but it does not follow that all Powers are ghosts and spirits, even if they tend to become so. In what follows I propose that we examine a few typical cases of Powers, which, beneath the animistic colour that in the course of time has more or less completely overlaid them, show traces of having once of their own right possessed pre-animistic validity as objects and occasions of man's religious feeling.

Let us start with some cases that, pertaining as they do to the "Unknown Without" as it appears in most direct contradistinction to the "Unknown Within," are thus farthest removed from the proper domain and parent-soil of Animism, and may therefore be supposed to have suffered its influences least. What we call "Physical Nature" may, very well be " nature" also to the savage in most of its normal aspects; yet its more startling manifestations, thunderstorms, eclipses, eruptions, and the like, are eminently calculated to awake

1 The Greek word that comes nearest to "Power" as used above is Tŕpa". Perhaps "Teratism" may be preferred as a designation for that attitude of mind which 1 have termed "Supernaturalism.". 
in him an Awe that I believe to be specifically religious both in its essence and in its fruits, whether Animism have, or have not, succeeded in imposing its distinctive colours upon it. Thus, when a thunderstorm is seen approaching in South Africa, a Kaffir village, led by its medicine-man, will rush to the' nearest hill and yell at the hurricane to divert it from its course. ${ }^{1}$ Here we have Awe finding vent in what on the face of it may be no more than a simple straightforward act of personification. It is Animism in the loose sense of some writers, or, as I propose to call it, Animatism; but it is not Animism in the strict scientific sense that implies the attribution, not merely of personality and will, but of "soul" or "spirit," to the storm. The next case is but slightly different. The Point Barrow natives, believing the Aurora Borealis to do them harm by striking them at the back of the neck, brandish knives and throw filth at it to drive it away. ${ }^{2}$ Now I doubt if we need suppose Animism to be latent here any more than in the African example. Nevertheless the association of the Aurora's banefulness with a particular malady would naturally pave the way towards it, whilst the precautionary measures are exactly such as would be used against spirits. The following case is more dubious. When a glacier in Alaska threatened to swallow up a valuable fishing stream two slaves were killed in order to bring it to a standstill. ${ }^{3}$ Here the advanced character of the propitiatory rite probably presumes acquaintance with some form of the animistic theory. It may very well be, however, that sacrifice is here resorted to as a general religious panacea without involving any distinct recognition of a particular glacier spirit. And now let us take a couple of instances where the theory behind the religious observance is more explicit. The Fuegians

${ }^{1}$ Macdonald, $J . A . ~ I ., ~ x i x ., 283$.

2 Murduch, Point Barrow Expedition, 432.

'Peet, Ant. Antiq., ix., 327; an instance, however, that might be better authenticated. 
abstain from killing young ducks on the ground that if they do, "Rain come down, snow come down, hail come down, wind blow, blow, very much blow." The storm is sent by a "big man" who lives in the woods." Now is this Animism? I think not. What may be called a "coincidental marvel". is explained by a myth, and Mythology need be no more than a sort of Animatism grown picturesque. When, however, a Point Barrow Esquimaux, in order to persuade the river to yield him fish, throws tobacco, not into the river but into the air, and cries out "Tuana, Tuana" (spirit), then here is full-fledged Animism. Meanwhile, whatever view be taken of the parts respectively played by Animatism, Mythology, Animism, or what not, in investing these observances with meaning and colour, my main point is that the quality of religiousness attaches to them far less in virtue of any one of these ideal constructions than in virtue of that basic feeling of Awe, which drives a man, ere he can think or theorise upon it, into personal relations with the Supernatural.

In order to establish the thesis that the attitude of Supernaturalism towards what we should call Inanimate Nature may be independent of animistic interpretations, much more is required in the way of evidence than what I have the space to bring forward here. In the case of matters so indirectly ascertainable as the first beginnings of human thought, the cumulative testimony of very numerous and varied data affords the only available substitute for crucial proof. As it is, however, I must content myself with citing but two more sets of instances bearing on this part of my subject.

The first of these may be of interest to those who have lent their attention to $\mathrm{Mr}$. Lang's recent discovery of "Pure"-that is to say, Ethical-Religion in the wilds of .

1 Fitzroy, ii., I80.

'Murdoch, ib., 433. 
Australia. I have to confess to the opinion with regard to Daramulun, Mungan-ngaur, Turndun, and Baiamai, those divinities whom the Kurnai, Murrings, Kamilaroi, and other Australian groups address severally as "Our Father," recognising in them the supernatural headmen and lawgivers of their respective tribes, that their prototype is nothing more or less than that well-known material and inanimate object, the bull-roarer. Its thunderous booming must have been eminently awe-inspiring to the first inventors, or rather discoverers, of the instrument, and would not unnaturally provoke the "animatistic" attribution of life and power to it. Then Mythology seems to have stepped in to explain why and how the bull-roarer enforces those tribal ceremonies with which its use is associated, and, after the manner of Myth, to have invented schemes and genealogies of bullroarers whose wonderful history and dreadful powers it proceeded to chronicle. Thus, for example, Baiamai kills Daramulun for devouring some of the youths undergoing initiation, but puts his voice into the wood of the bullroarer. . Or Mungan-ngaur begets Turndun, who first makes the bull-roarers in actual use amongst the Kurnai, and then becomes a porpoise. ${ }^{2}$ Further, Mythology is reinforced by symbolistic ritual. Figures made of logs are set up on the initiation ground to represent Baiamai and his wife; or the men throw blazing sticks at the women and children as if it were Daramulun coming to burn them. ${ }^{3}$ As for Animism, however, we never get anywhere near to it save perhaps when Daramulun's voice is said to inhabit the bull-roarer, or when he is spoken of as living in the sky and ruling the ghosts of the dead Kurnai." Nevertheless, despite its 'want of animistic colouring, a genuine Religion (if reverence shown towards supernatural powers

' Matthews, J. A. I., xxv., 298.

Howitt, J. A. I., xiv., 312.

- Matthews, J. A. I., xxiv., 4 I6 ; xxv., 298.

1 Howitt, J. A. I., xiv., $32 \mathrm{r}$. 
and obedience to their mandates be a sufficient test of genuineness) has sprung up out of the Awe inspired by the bull-roarer; and Mr. Lang's assertion may safely be endorsed that Animism, with the opportunities it affords for spiritualistic hocus-pocus, could serve to introduce therein a principle of degeneration only.

My other set of instances pertains to the fascinating subject of stone-worship-a subject, alas! from which I would fain illustrate my point at far greater length. Stones that are at all curious in shape, position, size, or colour-not to speak of properties derived from remarkable coincidences of all sorts-would seem specially designed by nature to appeal to primitive man's "supernaturalistic" tendency. A solitary pillar of rock, a crumpled volcanic boulder, a meteorite, a pebble resembling a pig, a yam, or an arrowhead, a piece of shining quartz, these and such as these are almost certain to be invested by his imagination with the vague but dreadful attributes of Powers. Nor, although to us nothing appears so utterly inanimate as a stone, is savage animatism in the least afraid to regard it as alive. Thus the Kanakas differentiate their sacred stones into males and females, and firmly believe that from time to time'little. stones appear at the side of the parent blocks. ${ }^{l}$ On the other hand; when a Banks' Islander sees a big stone with little stones around it, he says that there is a $V u i$ (spirit) inside it, ready if properly conciliated to make the women bear many children and the sows large litters. ${ }^{2}$ Now, this is no longer Animatism, but Animism proper. A piece of sympathetic magic is explained in terms of spirit causation. The following case from the Baram district of Borneo is transitional: A man protects his fruit trees by placing near them certain round stones in cleft sticks. He then utters a curse, calling upon the stones to witness it: "May he whio steals this fruit suffer from stones in the stomach as large as

1 Ellis, Tour round Hawaii, 113.

2 Codrington, J. A. I., $\mathrm{x}, 276$. 
these." Further, suppose a friend of the proprietor wish to eat of the fruit, he will light a fire, and ask the fire to explain to the stone that nothing wrong is being done. ${ }^{1}$ Here we seem to have simple Animatism, but it may be said to tremble on the verge of Animism, inasmuch as by itselfthat is, by the mere attribution of life and will-it is unable to account for the magical powers of the stone. How this may be done with the help of Animism is shown us by the Banks' Islanders, already referred to, who, employing stones of a peculiar long shape in much the same way to protect their houses, do so on the explicit ground that the stones have "eaten ghost." - the ghost of a dead man being not unnaturally taken as the type and ne plus ultra of awful power. ${ }^{2}$ Not to multiply instances, let me roundly state that amid the vast array of facts relating to the worship of stones, there will be found the most divergent ideal representations of their supernatural nature and powers, ranging from the vaguest semi-conscious belief in their luckiness, ${ }^{3}$ onwards through Animatism, to the distinct animistic conception of them as the home of spirits of the dead or the unborn, or as the image and visible presence of a god; but that underlying all these fluctuating interpretations of thought there may be discerned a single universal feeling, namely the sense of an Awfulness in them intimately affecting man and demanding of him the fruits of Awe, namely respect, veneration, propitiation, service.

Passing now from the region of what we regard as the. Inanimate to that of the Sub-animate and the Animate, we come first in order of upward progress to that tantalising

\footnotetext{
- Hose, J. A. I., xxiii., 161.

2 Codrington, l.c.

' I' am afraid it may be said that I have not given sufficient prominence to that "moment" in religious feeling which corresponds to the belief in Luck. I do not, however, regard it as a specific emotion in itself, but rather as a compound of the Wonder produced by a coincidence and of sufficient Awe of the power therewith seemingly connected, to make it appear worth while to try to conciliate it.
} 
theme, the worship of plants and animals. Now to a large extent this coincides with the subject of Totemism, about which I shall say little, if only because it teems with controversial matter. This much, however, I take to be now relatively certain with regard to it, that in their origin totemistic observances had a magical rather than a strictly religious import. That is to say, their object was not so much to conciliate powers in plant or animal form, as to establish sympathetic control over classes of serviceable plants and animals regarded simply as such, namely as clans or tribes very much on a par with the human ones. Now I am ready to suppose that sympathetic magic in the eyes of the savage is, primarily, no exclusive instrument of religion, but a means of causation on a level with his other methods of exerting force-just as with him talking is not confined exclusively to praying. On the other hand, I believe that the abnormal, and mysterious element in magical causation is bound to strike him sooner or later, and to call for explanation in the terms most familiar and most satisfying to primitive mysticism. Thus, in the case of Totemism, the conception of an affinity between the spirits of the plants and animals and their human clients, as effected by Transmigration or some other animistic contrivance, is sure to arise, with the result that the plants and animals by reason of their "spiritualisation" forthwith assume the plenary rank and attributes of Powers. Meanwhile, in order to show how this may come about, I shall bring forward one or two illustrations that have no direct connection with Totemism, as they will then at the same time serve to call attention to the qualities that constitute an intrinsic as opposed to a merely derivatory right to be revered as Supernatural and Awful. There are many animals that are propitiated by primitive man neither because they are merely useful nor merely dangerous, but because they are, in a word, uncanny. White animals (for example, white elephants or white buffaloes), birds of night (notably the owl), monkeys, mice, frogs, crabs, 
snakes, and lizards, in fact a host of strange and gruesome beasts, are to the savage, of their own right and on the face of them, instinct with dreadful divinity. 'To take a single instance, a fishing party of Crees catch a new and terriblelooking kind of fish. It is promptly returned to the water as a Manitou, and five days are wasted whilst it is being appeased. I Now in the case of Powers like these, sympathetic magic will naturally suggest the wearing of tooth or claw, bone or skin as a means of sharing in the divine potency. Here is the chance for Animism to step in. Thus a Kennaiah chief who wishes to wear the skin of the Borneo tiger cat for luck in war, will wrap himself in it, and before lying down to sleep will explain to the skin exactly what he wants; and beg the spirit to send him a propitious dream. ${ }^{2}$ $O r$ in other cases mere association and coincidence will pave the way, towards an animistic version of the facts. Thus I have no doubt that it is the uncanny appearance of the snake, combined with its habit of frequenting graves and of entering dwellings, which has led more than one savage people to treat it as the chosen incarnation of their ancestral ghosts. ${ }^{3}$ And here let me leave this part of the subject, having thus barely touched upon it in order to confirm the single point that Religious Awe is towards Powers, and that these are not necessarily spirits or ghosts, though they tend to become so.

At length we reach what I have roughly described as the proper domain and parent-soil of Animism, namely the phenomena that have to do with dream and trance, disease and death. Here the question for us must be, "Do Super. naturalism and Animism originally coincide in respect to these phenomena?" Or, in other words, "Is the Awful in each and all of them alike, primarily soul or spirit?" $\mathrm{My}$

Hind, Red River Exped, ii., 135.

2 IIose, $J$. A. I., xxiii., 159. 227.

" "Zulus," Macdonald, J. A. I., xx., 1 z2. " Malagasy," Sibree, J. A. I., xxi., VOL. XI. 
own belief is that the two spheres do not originally coincide, that the Awful in dream and trance is at first distinct from the Awful in death and disease, though the former readily comes to overlay and colour the latter. Thus I conceive that the trance-image, alike on account of its" singularity, its accompaniments in the way of physical no. less than mental derangement, and its coincidental possibilities, must have been originally and of its own right Awful; and that so, though perhaps to a lesser extent, must have been the dream-image, if only on the ground last mentioned. Nor would I deny that, in regard to death, these two kinds of vision taken together would be bound to suggest to the savage mind that there is a something which survives the body. But have we here a complete account of the influences whereby there is produced that mingled fear and love of the dead which culminate in Manes-worship? I think not. For one thing, it is almost an axiom with writers on this subject, that a sort of Solipsism, or Berkleianism (as Professor Sully terms it as he finds it in the Child), operates in the savage to make him refuse to recognise death as a fact, there being at any rate plenty of proof that he is extremely unwilling to recognise the fact of natural death. The influence, however, which I consider most fundamental of all is something elsenamely the awfulness felt to attach to the dead human body in itself. Here, I think, we probably have the cause of the definite assignment to a passing appearance like the trance-image of real and permanent existence in relation to a dead owner; and certainly the main source of the ascription of potency to the soul thus rendered substantive. The thrill of ghost-seeing may be real enough, but I fancy it is nothing to the horror of a human corpse instilled into man's heart by his instinct of self-preservation. In confirmation of this view I would refer to the mass of evidence dealing with the use of human remains for purposes of protective or offensive magic. A skull, a human hand, a scalp-lock, a 


\section{Pre-animistic Religion.}

portion of dried and pounded flesh are potent medicine in themselves, so long as sympathetic magic is at the stage at which it takes itself for granted. Magical processes, how. ever, as we have seen, specially invite explanation. What more natural then, given an acquaintance with the images of trance and dream, than to attribute the mysterious potency of a dead man's body to that uncanny thing his wraith? Let me quote just one instance to show how easy is the transition from the one idea to the other. A young native of Leper's Island, out of affection for his dead brother, made his bones into arrow-tips. Thereafter he no longer spoke of himself as "I," but as "we two," and was much feared.2 The Melanesian explanation was that he had thus acquired the mana, or supernatural power, of the dead man. Clearly it is but a hair's breadth that divides the mana thus personified from the notion of the attendant ghost, which elsewhere so often meets us.

There remains the difficult question whether Animism is primarily, or only derivatively, connected with the religious Awe felt in the presence of most kinds of disease. I am disposed to say "distinguo." As regards delirium, epilepsy, and kindred forms of seizure, the patient's experience of hallucinatory images, combined with the bystanders' impression that the former is, as we say, "no longer himself," would, I think, wellnigh immediately and directly stamp it as a case of possession by a spirit. Then all convulsive movements, sneezing, yawning, a' ringing in the ear, a twitching of the eyelid, and so on, would be explained analogously. On the other hand there is a large and miscellaneous number of diseases that primitive man attributes to witchcraft, without at the same time necessarily ascribing them to the visitation of bad spirits. Thus a savage will imagine that he has a crab or a frog, some red ants or a piece of crystal, in his stomach, introduced by magical means, as for instance by burying the crab (perhaps with

' Codrington, J. A. I., xix., 216.7 . 
an invocation to the crab-fetish) ${ }^{l}$ in his path. $\quad$ To remedy such supposed evils the native doctor betakes himself to the sucking cure and the like, whilst he meets spirits with a more or less distinct set of contrivances, for instance the drum or rattle to frighten them, and the hollow bone to imprison them. Meanwhile Animism undoubtedly tends to provide a general explanation for all disease, since disease to the savage mind especially connotes what may be described as "infection" in the widest sense, and infection is eminently suggestive of the workings of a mobile aggressive agency such as spirit appears intrinsically to be. Let me briefly refer, however, to one form of malady which all the world over excites the liveliest religious Awe, and is yet, so far as I know, but rarely and loosely connected with Animism by savage theorists. The horror of blood I take to be strictly parallel to the horror of a corpse already alluded to ; and I believe that in what Westermarck has termed the "mystic detestation" of woman, or in the unreasoning dread which causes a North American brave with a running sore to be banned from the camp, ${ }^{2}$ we have a crucial case of a pure and virtually uncoloured religious feeling. The issue of blood "pertains to Wakanda," as the Omahas said..$^{8}$ That is the primary vague utterance of Supernaturalism; and strictly seçondary, I conceive, and by way of ex post facto justification, is the belief in the magical properties of the blood, the theory that the blood is the life, or the Maori notion that it is full of germs ready to turn into malicious spirits.".

At this point my list of illustrations must come to a close; and it therefore only remains for me to utter a last word in my own defence for having called attention to a subject that many will be ready to pronounce both trite, and at the same time incapable of exact or final treatment.

\footnotetext{
1 Conolly, J.A. I., xxvi., $15 \mathrm{I}$.

2 Adair, Hist. of Am. Ind., 124 .

- Dorsey, Omaha Sociology, 267.

- Cf. Tregear, J. A. L., xix., Ior.
} 
As regards the charge of triteness, I would only say that a disregarded commonplace is no commonplace at all, and that disregard is, anthropologically speaking, to be measured by the actual use to which a conception is put when there is available evidence in the shape of raw facts waiting to be - marshalled and pigeon-holed by its aid. I do not find that the leading theorists have by the organisation of their material shown themselves to be sufficiently aware that the animistic idea represents but one amongst a number of ideas, for the most, part far more vague than it is, and hence more liable to escape notice; all of which ideas, however, are active in savage religion as we have it, struggling one with the other for supremacy in accordance with the normal tendency of religious thought towards uniformity of doctrinal expression. On the contrary, the impression left on my mind by a study of the leading theorists is that animistic interpretations have by them been decidedly overdone; that, whereas they are prone in the case of the religions of civilisation to detect survivals and fading rudimentary forms, they are less inclined to repeat the process when their clues have at length led them back to that stage of primitive thought which perforce must be "original" for them by reason of the lack of earlier evidence, but is not in the least "original" in an absolute sense and from the standpoint of the racial history.

As for the charge of inconclusiveness, this might be in point were it a question of assigning exact limits to the concept to which the word Religion, as employed by Anthropology, ought to correspond. As I have said, however, the only real danger at present can come from framing what is bound to be a purely experimental and preliminary definition in too hard-and-fast a manner. Thus Mr. Frazer, though he is doubtless well aware of all the facts I have cited, prefers to treat of Magic and Religion as occupying mutually exclusive spheres, whilst I regard these spheres, not indeed as coincident by any means, but still as over- 
lapping. I, on the otner hand, would hold out for the widest possible rendering of the idea of Religion on practical and theoretical grounds alike. As regards the former, I should fear to cut myself off prematurely from any group of facts that might possibly bear upon the history of man's religious evolution. As regards theory, I would rest my case on the psychological argument that, if there be reason, as I think there is, to hold that man's religious sense is a constant and universal feature of his mental life, its essence and true nature must then be sought, not so much in the shifting variety of its ideal constructions as in that steadfast groundwork of specific emotion whereby man is able to feel the supernatural precisely at the point at which his thought breaks down. Thus, from the vague utterance of the Omaha, "the blood pertains to Wakanda," onwards through Animism, to the dictum of the greatest living idealist philosopher "the Universe is a Spiritual Whole,". a single impulse may be discerned as active-the impulse, never satisfied in finite consciousness yet never abandoned, to bring together and grasp as one the That and the What of God.

\section{WEDNESDAY, FEBRUARY 21st, 1900.}

The President (Mr. E. Sidney Hartland) in the Chair.

THE minutes of the last Meeting were read and confirmed.

The election of the following new Members was announced, viz.: Mr. R. Blakeborough, Mr. E. -im Thurn, Mr. Bernard Hamilton, Mr. P. J. Heather, Dr. W. H. R. Rivers, and Mr. Ralph Shirley.

The deaths of Mr. J. Kermack and Mrs. C. M. Layton and the resignations of Mr. A. H. Diack and Mr. J. F. Gomme were also announced. 
The President exhibited the following: Dentalium shells from the North West Coast of America, used by the tribes of British Columbia for currency and ornament, which had been sent by Mr. W. Corner, of Wellington, Somerset, and presented by him to the Society; a photograph of a basrelief at Welton Farm House, Blairgowrie, with a note thereon by Mr. E. K. Pearce, by whom the photograph had been taken (infra, p. 211); an engraving by W. Woollett representing a tropical scene, and a water-colour drawing representing a dance of native Australians, said to have been painted by a native Australian, sent by Mr. Emslie. A vote of thanks was accorded to the contributors.

The following books and pamphlets, presented to the Society since the last Meeting, were laid upon the table, viz.:-

Superstizioni, Pregiudizi, e Tradizioni in Terra d' Otranto, by Giuseppe Gigli; Pipes and Smoking Customs of the American Aborigines, based on material in the U.S. National Museum, by Joseph D. McGuire; Te pito te Herina, known as Rapa nui, commonly called Easter Island, South Pacific Ocean, by George H. Cooke; The Man's Knife among the North American Indians, by Otis Tufton Mason; and Arrowheads, Spearheads, and Knives of Prehistoric Times, by Thomas Wilson, all presented by the President; Lud, Organ Towarzystwa Ludoznawcaego we Lwowie, Tome vi., Part $\mathrm{I}$; the following pamphlets by Dr. R. Lasch, all presented by the author, viz.: Über Geophagie; Religiöser Selbstmord und Seine Beziehung zum Menschenopfer; Rache als Selbsmordmotiv; Die.Behandlung der Leiche des Selbstmorders; and Der Selbstmord aus Erotischen Motiven bei den primitiven Völkern; and Contes populaires de Languedoc, by Louis Lambert, presented by Mrs. Janvier.

Professor Haddon delivered a lecture on the "Toys and Games of Papuan Children," which was illustrated by lantern slides; after which Dr. W. H. R. Rivers and Mr. Ray 
gave some illustrations of the game of Cat's Cradle as practised by the Papuans. Votes of thanks were accorded to Professor Haddon for his lecture and to Dr. Rivers and Mr. Ray for their exhibition.

\section{WEDNESDAY, MARCH 21st, 1900.}

Mr. G. L. Gomme, Vice-President, in the Chair.

THE Minutes of the last Meeting were read and confirmed.

The resignations of Comte de Charencey and Mr. J. Barwell were announced. The election of Judge F. Baker was also announced.

Miss Grove exhibited some photographs of Bacchanalian dances on sarcophagi at Rome and Pompeii.

The Secretary read a note by Miss, E. Skeffington Thompson, on the First-Foot Superstition in Lancashire (infra, p. 220), upon which the Rev. E. W. Clarke and Mr. Emslie offered some observations.

Mr. E. K. Chambers read a paper entitled "The Feast of Fools,". and in the discussion which followed Mr. Emslie, Mr. Bouverie Pusey, the Rev. E. W. Clarke, and the Chairman took part.

A vote of thanks was accorded to. Mr. Chambers for his paper.

The following short papers were also read:-

"Notes on Korean Folklore," by the Rev. J. S. Gale; "Horses' Heads, Weathercocks, \&c.," by Mr. N. W. Thomas; "The Bumble Bee in Folklore," by Miss M. Peacock; and a note on the Japanese legend of Ama Terasu, by Miss Louise Kennedy. 